\title{
Collaborative Meeting as an Integrative Mechanism in a Multinational Investment Project
}

\author{
Leena Pekkinen, Jaakko Kujala \\ Department of Industrial Engineering and Management, University of Oulu, Oulu, Finland \\ Email: leena.pekkinen@pp1.inet.fi, jaakko.kujala@oulu.fi
}

Received December 21, 2013; revised January 21, 2014; accepted January 28, 2014

Copyright (C) 2014 Leena Pekkinen, Jaakko Kujala. This is an open access article distributed under the Creative Commons Attribution License, which permits unrestricted use, distribution, and reproduction in any medium, provided the original work is properly cited. In accordance of the Creative Commons Attribution License all Copyrights (C) 2014 are reserved for SCIRP and the owner of the intellectual property Leena Pekkinen, Jaakko Kujala. All Copyright (C) 2014 are guarded by law and by SCIRP as a guardian.

\begin{abstract}
In multinational and complex projects that are often implemented by multiple organizations, the entire projects need to be divided into manageable subprojects. At the same time, all subprojects are needed to be kept aligned with the project goals and targets by integration and coordination. The purpose of this article is to study the role of a particular, work-shop type, collaborative meeting by utilizing the characteristics of an integrative information processing framework. A single case study method was used to observe the practices of collaborative meetings. This study contributes to the project management research by analysing how collaborative meeting practice can be used as a mechanism to reduce uncertainty and equivocality in a large investment project. The results of this study are two folds: Firstly, the case project's collaborative meetings are described in detail; secondly, the perceived features and procedures of the collaborative meetings in the case project are illustrated showing the role of the collaborative meetings as an integrative tool. Moreover, the perceived integrative characteristics of the collaborative meetings reducing uncertainty and equivocality are presented. This study indicates that collaborative meeting is an integrative mechanism reducing uncertainty and equivocality in a large investment project context.
\end{abstract}

\section{KEYWORDS}

Collaboration; Integration; Coordination; Uncertainty; Equivocality

\section{Introduction}

Large international investment projects are increasingly carried out as networks of different organizations and they integrate resources and competencies from multiple firms and organizational units inside firms [1,2]. The project work breakdown system and the division of the project into subprojects are important approaches for the management of this type of project [3-6]. The division of work and participation of multiple organizations in a project create challenges on how to integrate various organizational units to enable effective coordination of project work. Projects confront uncertainty and equivocality of information, which also challenge integration and coordination in the projects. Uncertainty and equivocality have their origin in the environment, the technology and the increased number of the related actors and partners in a large investment project context [7-9].
In multinational, complex and partly virtual projects, all subprojects must be kept aligned with the project goals and targets using integration and coordination practices. In practice, a collaborative meeting in which personnel from different organizations identify and agree on core issues related to project implementation has been suggested as an effective approach to overcoming challenges of integration and coordination. In this research we aim to understand how collaborative meetings enhance integration and coordination by reducing uncertainty and equivocality in the context of a multinational investment project.

The theoretical basis of our research is information processing perspective [10-12]. From this perspective, integration and coordination mechanisms refer to the information processing practices and structures of organizing. Our research builds on existing research on inte- 
gration and coordination in the context of project management. It has been studied recently in an R\&D project context $[13,14]$, in a complex project that emphasized buyer-supplier relationships [15], in the software project context [16], in the high-technology semiconductor industry environment [17] and in construction project context [18]. Also integration inside a project-based company has been the focus of some current research with a focus on the integration of sales and functions of the project operations [19-21].

A single case study method was selected to empirically research practices of collaborative meetings to reduce uncertainty and equivocality in a multinational investment project executed by several global companies. An in-depth description of the collaborative meeting is presented and analysed to portray activities in a collaborative meeting, the kinds of issues that are discussed, how these issues are handled and how a collaborative meeting supports integration in a large investment project.

\section{Literature Review}

\subsection{Integration and Coordination Mechanisms}

The integration techniques and coordination mechanisms are presented by many scholars [8,11,22-24]. The integration and coordinating mechanisms presented by the scholars are typically classified into two groups; impersonal mechanisms based on authority and subtle mechanisms based on informal communication models and practices $[10,11]$. Impersonal mechanisms are the most useful in cases where project targets and goals can be formulated according to available information. Subtle mechanisms are needed in the cases of complex and ambiguous project setups where the primary function of information processing is to understand the main issue [25-27].

Galbraith presents impersonal, mechanistic model consisting of three elements to integrate the subtasks; 1) coordination by rules and programs, 2) hierarchy and 3) coordination by targets and goals [10]. Impersonal tools include e.g a project plan, an organization intranet, meeting minutes, case writing, project history files and a da- tabase of lessons learnt. Martinez and Jarillo categorize impersonal coordination mechanisms into the following categories: departmentalization, centralization, formalization and standardization, planning and output and behavioral control [12]. These categories are akin to the Galbraith's coordination mechanisms. Martinez and Jarillo also introduce three groups of subtle integration mechanisms: informal communication, lateral or crossdepartmental relations and socialization [12]. It should be noted that some mechanistic, impersonal integration mechanisms e.g. formal meetings can also have elements of subtle mechanisms. Impersonal and subtle integration mechanisms presented by Daft and Lengel have many similar elements as the frameworks introduced by Galbraith and Martinez and Jarillo. Three above mentioned integration frameworks are summarized in Table 1.

In this study the framework of integration mechanisms introduced by Daft and Lengel is used as a theoretical foundation [11]. They propose seven integrative mechanisms that fit along a continuum with respect to the organizations capacity for reducing uncertainty or for reducing equivocality. The integrative mechanisms are: 1) group meetings, 2) integrators, 3) a direct contact, 4) planning, 5) special reports, 6) formal information systems and 7) rules and regulations.

\subsection{Managing Uncertainty and Equivocality}

Project organizations encounter various contingency factors arisen from the uncertainty and the equivocality $[7,22,23]$. Uncertainty is seen as a lack of information and equivocality is seen as ambiguity, the existence of multiple and conflicting interpretations. Daft and Lengel note that a company processes information as a response to the requirement to manage uncertainty and equivocality related to the technology, the inter-department relations and the environment. Under the conditions of high uncertainty, the organization acquires data to answer a variety of objective questions. Under the conditions of high equivocality managers exchange opinions to clarify ambiguities, define problems and reach an agreement. Organizations need different kind of mechanisms to manage uncertainty and equivocality they face [11].

Table 1. Summary of integrating mechanisms presented in the literature.

\begin{tabular}{|c|c|c|c|}
\hline Type of integration & Daft and Lengel (1986) & Galbraith (1974) & Martinez and Jarillo (1989) \\
\hline \multirow[t]{4}{*}{ Impersonal mechanisms } & Rules and regulations & Coordination by rules and programs & Departmentalization centralization \\
\hline & Formal information systems & Hierachy & Formalization standardization \\
\hline & Special reports & & Planning \\
\hline & Planning & & Output and behavior control \\
\hline \multirow[t]{3}{*}{ Subtle mechanisms } & Direct contact & Coordination by targets and goals & Informal communication \\
\hline & Integrator & & Lateral or cross-departmental relations \\
\hline & Group meeting & & Socialization \\
\hline
\end{tabular}


Impersonal mechanisms introduced Daft and Lengel, Galbraith and Martinez and Jarillo including predefined practices and models, rules, regulations, reports and formal information systems, are needed to handle situations when uncertainty needs to be reduced [10-12]. Rules, project plans and minutes of meetings provide a response to the predictable situations which can be managed by gathering information. Daft and Lengel as well as Martinez and Jarillo present subtle mechanisms e.g. group works, a role of integrator and direct contacts as means to reduce equivocality caused by different meanings and interpretations. Subtle mechanisms emphasize social aspects of information processing and utilize direct face-toface contacts in situations when consensus of the main issues is needed.

\section{Methodology}

A single case study was selected for the study of contextual integration in a large, complex investment project. A qualitative research method was used to empirically study the practices and the procedures of integration in a multinational investment project executed by several global companies [28]. The selected case project represents a large international project with numerous actors from different cultures. The selected case project was the most interesting one due to the collaborative meeting process that it involved.

The collaborative meeting process consists of a pre work conducted by moderators to identify key issues and concerns that were to be handled during the collaborative meeting. The meeting involved two kinds of working practices. During part of the meeting, one person gave a presentation, while the rest of the meeting was spent in workgroups, where all participants could take an active role. One of the researchers was actively participating in the practical execution of the on-going investment project, working as one of the Project managers for the Main Contractor. She also participated in some part of the col- laborative meeting preparation processes together with representatives from the Builder and the moderators. In Table 2 the phases of the collaborative meeting and the parallel research process are shown. The role of the researcher in the collaborative meeting process is also displayed.

The research process was parallel to the collaborative meeting process and both of the processes had the same kind of activities. One of the researchers participated in both processes. She observed the pre-selection phase as well as the collaborative meeting and had an access to the data gathered during the meeting. Her observations, together with the data obtained during the pre-selection phase and the collaborative meeting phase were the important source of information. It has to be noted that researcher's role as a one of the Main Contractor's Project managers may bias to her observations.

In this study key individuals were interviewed. All of the interviewees played different roles in different companies involved in the multinational investment project. Interviews were semi-structured, lasting for 45 - 90 minutes. 9 people in different positions were interviewed: 2 project Steering Group members, the Builder's Project director, 2 Builder's Project managers, 2 Builder's project coordinators, the Main Contractor's scheduling coordinator and the Main Contractor's Project manager. The interviews were recorded, transcribed and their content was analysed. The empirical data was collected during the fifth collaborative meeting since the start of the investment project. This meeting was the second where the Main Contractor and the other contractors were present.

Interviews were conducted with questions that were designed to reveal attitudes towards collaborative meetings and the experiences that were gained. The positive aspects of the process as well as potential improvements were investigated. In the content analysis of the data, descriptions of the mechanisms and their roles from the

Table 2. Collaborative meeting process and parallel research process.

Collaborative meeting process

Preparation of the questionnaire

Participants answered to the questionnaire

Preselection

Input: answers to the questionnaire

Process: interview of key-persons

Output: selected issues for group work

Collaborative meeting

Input: 1) Prework in the form of questionnaires

2) Selected issues

Process: Group work "Issues and concerns"

Output: 1) List of actions

2) Personsible persons for the actions

3) Due dates of the actions

Implementation of the actions to the project plan
Research process during collaborative meeting

One of the researchers answered questionnaire

One of the researchers participated interviews as an observer, She did not participate in the pre-selection of issues.

One of the researchers participated the meeting and the group work.

One of the researchers made interviews during couple of days after the collaborative meeting 
point of view of integration were coded. Features of the collaborative meeting were then categorized based on the categories outlined in the literature review. Also examples of uncertainty and equivocality reduction during the meeting were identified. These were mainly from the discussions related to the risks identified during the collaborative meeting.

\section{Case Study: A Collaborative Meeting in a Multinational Investment Project}

The case project was established to build a brand new production line. The project started with a feasibility study in 2009. The Main contractor was selected at the beginning of 2011 aiming to the start-up the production line during the third quarter of 2013. The Builder decided to select only one Main Contractor who delivers all of the process departments of the production line. The scope of the delivery of the Main Contractor is large, including underground civil works, main equipment, auxiliary process systems, mechanical installation, electrification and instrumentation, the special training of the production line forthcoming operators and start-up services. Aside from the Main Contractor, there are several contractors delivering main auxiliary facilities e.g. logistics to the new site, chemicals on-site production and interconnections between several departments delivered by the Main Contractor. The Builder has hired a consultant taking part in purchasing, accounting and controlling. The Main Contractor is a global project-based company which delivers new production lines worldwide, production line departments and the modernization of those departments as an EPC contractor. The complex project network of the case project is presented in the Figure 1.

In the case project, collaborative meetings have been carried out since the feasibility study phase of the case project.

\subsection{Description of the Collaborative Meeting Procedure}

Collaborative meetings were arranged on a regular basis in the facilities near the site of new production line and outside of everyone's daily working environment. Since the project started there have been 7 collaborative meetings. The first three were held during the project feasibility study phase. The following collaborative meetings also included participants from the Main Contractor and from other contractors. The last two meetings were held within three months. A collaborative meeting lasts one and a half days. In the evening of the first day there was a dinner. This was a social event where the participants could get to know each other in an informal atmosphere.

PROJECT NETWORK

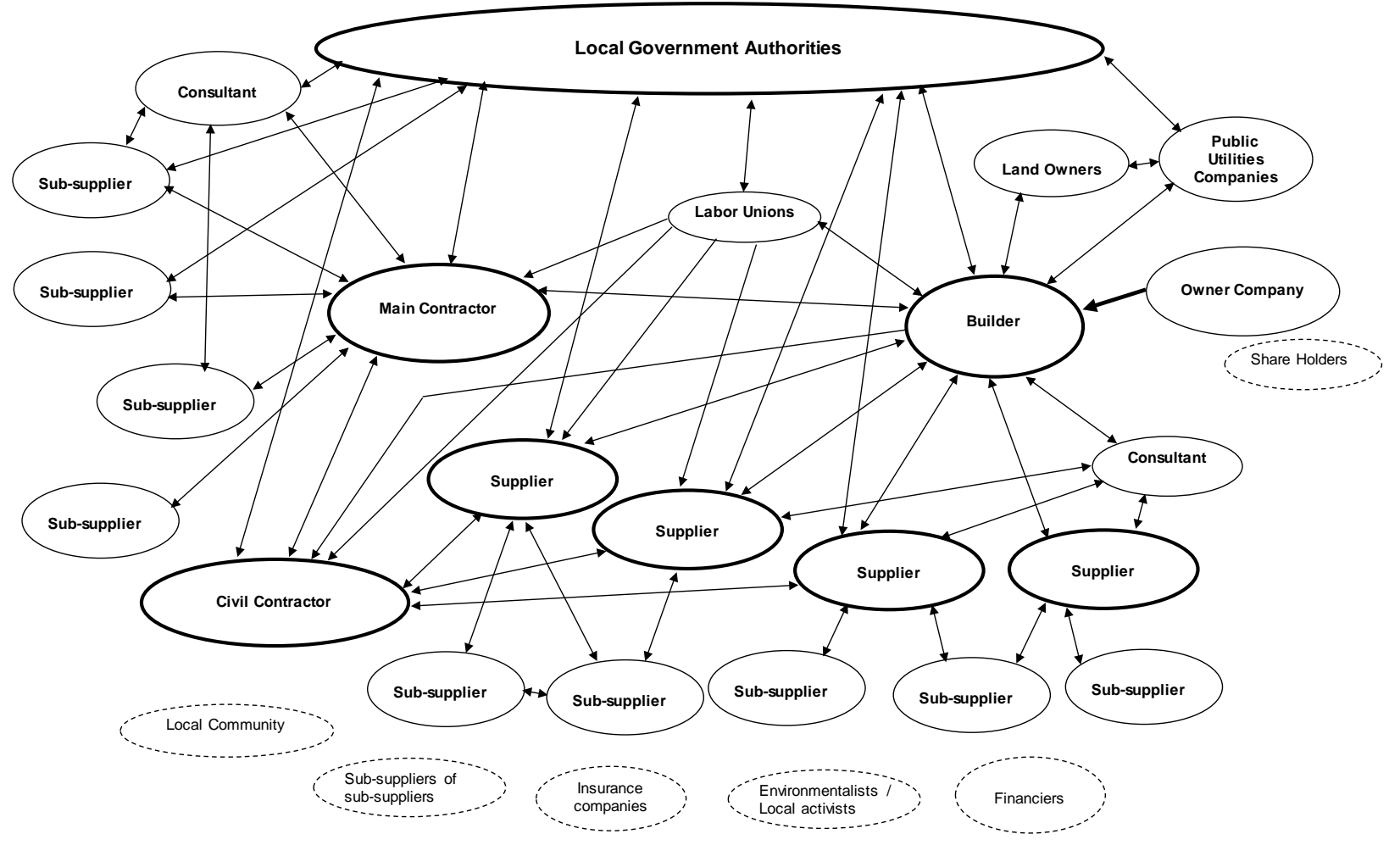

Figure 1. Project network. 
The collaborative meetings make a virtual organization visible for a while although there are only a few representatives from each of project actors' organizations present in the meeting. When considering all the workers including the contractors' sub-suppliers, the participants of the collaborative meetings represent only a small percentage of all the project members. In the two latter meetings there were more than hundred participants in the meeting. In the studied collaborative meeting, there were approximately 150 participants who represented 15 organizations. Half of the participants represented the Builder's project organization. There were more than ten nationalities present at the meeting.

There were two moderators who conducted the one and a half day's collaborative meeting session. The moderators have experience from many years of project management in global project-based companies and they also have many years' experience with mentoring work in this particular industry. During the meeting, two types of working practices were carried out. One part of the meeting was spent with a single person giving a presentation to an audience and part of the time was dedicated to group works where all participants gave their active input.

For the group work the participants were divided into 8 - 9 subgroups based on their discipline. The participants received the information about the meeting several weeks ahead of time. The participants were asked to fill in a questionnaire in which the important topics of the project were covered and participants raised issues. The moderators also interviewed Builder representatives before the collaborative meeting. Based on the answers to the questionnaire and the interviews a list of pre-set issues and concerns was created by the moderators. The program during the first half of the day consisted of greetings and a summary of the project status given by the owner, representatives of the Builder and all contractors. In the first half of the day a movie was also shown to the audience. The purpose of the movie was to create the appropriate atmosphere and spirit for the entire project team. The second half of the first day was dedicated to group works. Groups were established based on the participants of the Owner, the Builder and the contractors. The group work topic was "Issues and concerns" meaning important events, decisions, concerns and problems expected to arise or require special attention or follow-up in the next 60 - 90 days to ensure the success of the project outcomes. As an output of the group work actions to response the issues and concerns were agreed. The responsible persons were nominated for the agreed actions. The self evaluation of the project work executed so far was also included to the group work on the first day of the collaborative meeting. At the end of the first day there was a voting in which the participants' feeling of confidence in their ability to achieve outcomes was measured. The second day of the collaborative meeting was devoted to the risk management of the project. There was a group work to identify the risks and to evaluate their impact with the probability factor and the impact factor. The risk mitigation plan for the highest risk was determined and the responsible individuals were nominated.

As the result of the group work "Issues and concerns" and the "Risk session", action plans were created. The people responsible for specific actions were nominated to implement the specified actions to the project execution plan. The follow-up to the implementation of the actions will be done in the forthcoming collaborative meetings. The evaluation of the implementation progress between the collaborative meetings was not supervised by the moderators or any other project officers but was the responsibility of the appointed persons.

\subsection{Features of the Collaborative Meeting}

Based on the analysis, the experience of the interviewees of the collaborative meetings varies but is mainly positive. The cultural background and the general appreciation of the subtle coordination methods and tools affected individual experiences in the collaborative meetings. A big meeting in an environment away from an every day's working environment provides an opportunity to examine the project from a bird's eye view and from a project life span perspective. The project director of the Builder emphasizes the importance of the meeting by saying:

"This is a very good process. It is a simple process. We have experienced it positive for us. We had big problems and we have managed to solve them."

\section{Approach in the collaborative meetings}

Evidence was found that, in a collaborative meeting the approach to the project is different compared to the daily project work when operative challenges and problems are faced, handled and solved. In a collaborative meeting the perspective is widened and this facilitates a big picture view of the project and how one's own work fits into the project main objectives. In the "Issues and concerns" section of the collaborative meeting the issues were of the following nature 1) high importance due to high impact, 2) urgency because an immediate response is required, 3) concerns common between two or more actors/stakeholders and needing efforts from two or more actors/stakeholders and 4) complex, meaning that is not possible for a single stakeholder to solve an issue. In the collaborative meeting also wide and different perspec- 
tives are represented and presented. The member of the Steering Group, the representative of the Owner expressed the importance of the meeting as follows.

"This is a big effort. More than 150 persons are present. In this kind of investment project this kind of meeting gives an opportunity to bring out the voice of the owner."

The approach in the collaborative meeting shed light on the project life span, the entire project targets and the goals as well as the cooperation required between the different actors in the project.

\subsection{Coordination Mechanisms of the Collaborative Meeting}

Based on the empirical data, the collaborative meeting was characterized with the following terms: information sharing by subproject reviews, team creation, social event and group meetings, which will be described here in more detail.

\section{Information sharing by subproject reviews}

One of the main items on the agenda is the status and progress reports of the subprojects presented by corresponding subproject managers. The meeting having participants from all important active parties was an excellent opportunity to share and get information. In daily work, the different kinds of coordination meetings are limited mainly to their own organization and to only two to three main inter-actors. In a collaborative meeting where all important actors are present the message that the Owner and the Builder are presenting has a large audience as the member of the Steering Group states:

"This is a good way to get compact summary of the issues on a regular basis and to share information. Many people are gathered together and this is a good forum to really influence."

Information is shared at a general level by presentations given to the whole audience. More detailed information is shared and exchanged in the smaller groups and in the informal discussions around the coffee and lunch tables. The information shared in the meetings enables participants to get an overview of the entire project and gives an idea about the main activities and ongoing concerns. An example of common understanding is the influence that stakeholders' actions have on the progress of the project targets in the form of the time schedule. The uncertainty inherently present in a large investment project organization is reduced by the information shared by the inter-actors during a collaborative meeting.

\section{Team creation}

An investment project with many actors and stakeholders has a very dynamic, virtual organization. Thousands of people are working simultaneously towards a common goal. Project team members never meet all of their colleagues working in the other organizations of the entire project. The collaborative meeting is a representative forum for the entire project team to build up the spirit of "our team" as illustrated in the following quote from the Builder's Project manager:

"Personally I think it [collaborative meeting] creates enthusiasm and social energy. It binds us and makes us to work as a group."

\section{Social event}

The interviewees frequently brought up the social aspects of the collaborative meeting. The meetings were held in an environment outside the daily office work. Some participants traveled long ways to the meeting place. Many meeting participants overnight in the meeting facilities. During the meeting there are many opportunities for the participants to informally communicate with other project team members by changing opinions, getting the detailed information of the other subprojects, comparing experiences and creating social capital. The Builder's Project director puts this nicely into words as follows:

"This has also the social point of view. Very seldom, for example, supplier has an opportunity to meet one's competitors in an open environment and having a dinner and a beer together."

The analyzed data shows that one of the objectives of the collaborative meeting was to get team members from different organizations together and to work for common targets. The project director formulates this as follows:

"This is a unique opportunity to put all members together, including the competitors, to discuss of this specific project. Everyone discuss the same topics.”

Some participants were skeptical about the openness in the meetings as can be noted from the following citations from the Main Contractor Project manager and the Builder project coordinator.

\footnotetext{
"Are all in the meeting with open mind?"

"We are from different companies. We want to be
} 
apart from others. Sometimes we are too polite and do not arise the difficult issues."

\author{
Group meetings, "Issues and concerns" and "Risk ses- \\ sion"
}

During the collaborative meeting two group meetings were arranged to execute two group works. One group work handled "Issues and concerns" and the other one called "Risk session" concentrated on project risk management practices. The items discussed, handled and decided upon in these group meetings were partly same. The groups were established according to the functions of the investment project and the process departments and all groups had participants who were employees of the Owner, the Builder and the contractors.

\subsection{Coordination Mechanisms to Reduce Uncertainty and Equivocality}

During the collaborative meeting, participants can get an overall picture of the project. In a large project with several actors and hundreds of participants different opinions are found. In the collaborative meeting, participants get information directly from the responsible person and have an opportunity to ask further questions and discuss the details. Uncertainty is reduced by getting information directly from the responsible person as is stated by the scheduling coordinator from the Main Contractor:

"This [information sharing] is very useful for us. We get an overall picture of the entire project. All main actors are present and report their status, not only us."

Project participants get different and even conflicting messages about the issues involved both from rumors and from differing opinions heard in conversations and read in email-messages. The summarized information received from the responsible person in the collaborative meeting makes it possible to create a coherent view of the issues. Uncertainty experienced by participants is reduced when more information is shared, and more widely, uncertainty in the entire global project network is reduced when participants distribute the shared information in their home organizations.

In the collaborative meeting, a common understanding of the issues and concerns is reached and this results in a reduction in equivocality. Equivocality is reduced in the entire project network in terms of determining the most important issues that need to be solved. As one member of the Steering Group puts it, the group work succeeded in determining the most relevant issues.

"We had almost three days Steering Group meeting and 90 percent of the topics nominated in the last collaborative meeting were on the agenda. These topics are the current ones. With these we work continuously. The teams have recognized the right issues."

\subsection{Summary of the Empirical Findings}

In the collaborative meeting project participants had an opportunity to watch the project from a wider perspective and from the whole project lifespan. This approach differs from the daily approach which concentrates on operational duties and decision making. The collaborative meeting also gathered all main project participants together and created a team spirit among the participants. In the collaborative meeting, there were participants who represented the Owner's Steering Group. They benefitted most from information sharing, group meetings and informal discussions with all the main actors in the project, while some of the full-time project team members found the collaborative meeting was just a repetition of the issues that should have been handled as a part of the regular project work.

A large investment project confronts uncertainty and equivocality which have their origin in the complex settings of the project and in the contingency factors of the project. Uncertainty was reduced in the following ways 1) by using the special reports of the main issues and the status of the project and 2) by implementing response actions agreed upon in the collaborative meeting. Collaborative meetings as a big group event also have many informal features. We found out that the role of integrators, group works and informal discussions during the different occasions and events were elements which reduce equivocality. Table 3 presents the objectives/questions/tasks, integration mechanism, type of integration and the function of the collaborative meeting sub processes.

Pre-work, the pre-selection of issues, information sharing in the collaborative meetings, group work, team creation, social events as well as the implementation of response actions to the project plan are elements of the collaborative meeting which have a role in integration in the case investment project. The special reports and the planning are impersonal integration mechanisms. Based on evidence found in this study those impersonal integration mechanisms reduce uncertainty in the studied complex project. The role of integrators, direct contact and group works are subtle integration mechanisms that have an impact on reducing equivocality which many actors confront in the project work.

\section{Discussion}

This study contributes to emerging stream of project management research focusing on projects undertaken by multiple companies [29-31] by showing how the integra- 
Table 3. Objectives/questions/tasks, integrative mechanism, type of integration and the function of the collaborative meeting sub processes.

\begin{tabular}{|c|c|c|c|c|}
\hline $\begin{array}{l}\text { Sub processes of the collaborative } \\
\text { meeting }\end{array}$ & $\begin{array}{l}\text { Objectives/questions/tasks of the sub } \\
\text { process of the collaborative meeting }\end{array}$ & $\begin{array}{l}\text { Integrative } \\
\text { mechanism }\end{array}$ & Type of integration & Function of the sub process \\
\hline $\begin{array}{c}\text { Pre-work: } \\
\text { Information gathering via } \\
\text { questionnaires }\end{array}$ & $\begin{array}{l}\text { Main concerns of subprojects } \\
\text { Critical issues of subprojects }\end{array}$ & Special reports & Impersonal mechanim & $\begin{array}{c}\text { Reduction of uncertainty by } \\
\text { nominating concerns and } \\
\text { issues }\end{array}$ \\
\hline $\begin{array}{l}\text { Pre-selection of issues } \\
\text { Intergrators preselected main issues } \\
\text { and concerns based on questionnaires }\end{array}$ & $\begin{array}{l}\text { Priorization of the issues and concerns } \\
\text { Relevant for the entire project } \\
\text { Need input of many actors }\end{array}$ & Integrator & Subtle mechanism & $\begin{array}{c}\text { Reducing of equivocality by } \\
\text { prioritization }\end{array}$ \\
\hline \multicolumn{5}{|l|}{ Collaborative meeting } \\
\hline $\begin{array}{l}\text { Information sharing } \\
\text { Group work “Issues and concerns” }\end{array}$ & $\begin{array}{l}\text { Status reports of subprojects } \\
\text { Response actions }\end{array}$ & Special reports & Impersonal mechanism & $\begin{array}{l}\text { Reduction of uncertainty by } \\
\text { sharing information }\end{array}$ \\
\hline $\begin{array}{l}\text { Group work of issues and concerns in } \\
\text { the collabarorative meeting }\end{array}$ & $\begin{array}{l}\text { Resposbile persons } \\
\text { Due dates }\end{array}$ & $\begin{array}{l}\text { Direct contact } \\
\text { Group meeting }\end{array}$ & Subtle mechanism & $\begin{array}{l}\text { Reducing of equivocality by } \\
\text { focusing on specified } \\
\text { common agreed actions }\end{array}$ \\
\hline Team creation & Common goals & Direct contact & Subtle mechanism & $\begin{array}{l}\text { Reducing of equivocality by } \\
\text { commitment }\end{array}$ \\
\hline Social event & Get to know each other & $\begin{array}{l}\text { Direct contact } \\
\text { Group meeting }\end{array}$ & Subtle mechanism & $\begin{array}{l}\text { Reducing of equivocality by } \\
\text { increasing familiarity }\end{array}$ \\
\hline $\begin{array}{l}\text { Implementation of the actions to the } \\
\text { project plan. }\end{array}$ & Updating of the project plan & Planning & Impersonal mechanism & $\begin{array}{l}\text { Reducing of uncertainty by } \\
\text { proper plan }\end{array}$ \\
\hline
\end{tabular}

tion and coordination practices of information processing can reduce uncertainty and equivocality in a large investment project. Based on the empirical data both subtle and impersonal coordination mechanisms exist in collaborative meetings to align the targets for the entire project. The analysis of the empirical data proposes that the collaborative meeting can be characterized in the following terms: information sharing, team creation, commitment, prioritization by pre-selection and social events which can be seen as practices and tools for integration in a large investment project with many multinational actors. This study shows that integration mechanisms; communication, coordination, balance of member contribution, mutual support, effort and cohesion introduced by several scholars are essential also in a large investment project context [32,33].

\subsection{Integration Mechanisms to Reduce Uncertainty and Equivocality}

We observed both impersonal and subtle integrative mechanisms of collaborative meeting practice that reduce uncertainty and/or equivocality. Figure 2 depicts the integrative mechanisms [11] and the correspondence between those integrative mechanisms and the sub processes of the collaborative meeting. The underlined sub processes are not a part of the collaborative meeting but they complement a continuum of project execution work to utilize the outcomes of the collaborative meeting.

The collaborative meeting as a standardized and well structured meeting is a mechanistic tool of coordination. Our analysis shows that collaborative meetings emphasize goal setting as an integrating and committing instru- ment in the large investment project context. The importance of the goal setting from a team functioning point of view has been also argued by some scholar [34-36]. From the empirical data, there is plenty of evidence of the subtle integrative and coordinating mechanisms such as, team creation, commitment and social events which have their origin in the subtle mechanisms introduced in the literature. The common social aspect and the content of the meeting are aiming for commitment and team building by emphasizing the importance of the common and positive attitude and spirit. Subtle mechanisms utilize rich media in information processing. This notification is aligned with the studies of Shenhard and Kirkhaud who argue that subtle information mechanisms are preferred in a case of high risk contingency factors [36,37].

\subsection{Practical Implications}

In this study several elements of a collaborative meeting practice that reduced both uncertainty and equivocality were perceived. The collaborative meeting was characterized with the following terms: information sharing, team creation, prioritization by pre-selection and social events which can be seen as practices and tools for integration in a large investment project with many multinational actors. Based on this study a collaborative meeting with a formal structure and a well prepared agenda combined with many subtle integrative elements can be an effective project management tool particularly in the early stages of a project when many different and contradictory opinions exist.

This study gives many practical guidelines for arranging a collaborative meeting in a large investment project 
Integrative mechanism

Rules and Regulations

Uncertainty reduction (Obtain additional data, seek answers to explicit questions)

Equivocality reduction (Clarify, reach agreement decide which questions to answer )

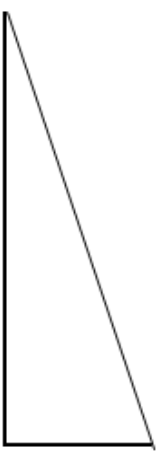

Special Reports

Planning
Collaborative meeting subprocesses and implementation to the project work

Everyday project work

Pre-work and Status report

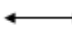

Implementation to the project plan

Group work "Issues and concerns"

Pre-selection

Social event, team creation

Figure 2. Sub processes of the collaborative meeting and implementation of its results to the project work.

context. Participants of a collaborative meeting have different needs of the collaboration e.g. the project manager needs more practical tools to support his/her work and the steering group member needs more general information about the entire project status. Based on the analysis, the experience of the interviewees of the collaborative meetings varies but is mainly positive. The cultural background and the general appreciation of the subtle coordination methods and tools affected individual experiences in the collaborative meetings. Full-time project team members might feel collaborative meeting less useful because of the common tendency to underestimate the need of information sharing [38]. Anyhow, with a properly and carefully organized collaborative meeting the entire project team can be aligned with common project goals and targets.

\section{Conclusions}

In large multinational investment projects, the integration of the subprojects is needed to enhance the achievement of common project goals. This study was carried out in order to uncover the role of collaborative meetings in integration by using the characteristics of an integrative framework from information processing theory. Integration is understood as the means of reducing uncertainty and equivocality in a large investment project. The single case study research method was selected to study the practices of the collaborative meeting and its integrative mechanisms.

First this study introduces the description of the collaborative meeting by providing a deeper understanding of the practices and meanings of the meeting. Secondly this study shows how the integrative mechanisms of collaborative meetings reduce uncertainty and equivocality and how the collaborative meeting enhances integration and coordination in the project. Collaborative meetings emphasizes the important role of goal setting as an instrument for encouraging integration and commitment in a large investment project context [34-36]. In addition, we propose subtle and personal practices as useful tools for project management for the purpose of integration and coordination to complement formal project management practices such as rules, regulations and plans. Hence, this study points out future research towards finding ways in which collaborative meetings can support project management work including the risk management in large projects.

\section{REFERENCES}

[1] K. Aaltonen, J. Kujala, P. Lehtonen, and I. Ruuska, “A Stakeholder Network Perspective on Unexpected Events and Their Management in International Projects," International Journal of Managing Projects in Business, Vol. 3, No. 4, 2010, pp. 564-588. http://dx.doi.org/10.1108/17538371011076055

[2] V. Turkulainen, J. Kujala, K. Artto and R. E. Levitt, “Organizing in the Context of Global Project-Based FirmThe Case Study of Sales-Operations Interface,” Industrial Marketing Management, Vol. 42, No. 2, 2013, pp. 223233. http://dx.doi.org/10.1016/j.indmarman.2012.08.004

[3] P. W. G. Morris and G. H. Hough, "The Anatomy of Major Projects-A Study of the Reality of Project Management,” John Wiley \& Sons, Chichester, 1987.

[4] P. W. G. Morris, "The Management of Projects," Sutton Courtenay, Oxfordshire, 1997. http://dx.doi.org/10.1680/mop.16934

[5] Project Management Institute, "A Guide to the Project Management Book of Knowledge (PMBOK)," 4th Edition, Project Management Institute, Newtown Square, 2008.

[6] APM, “APM Body of Knowledge,” 5th Editon, Association for Project Management, High Wycombe, 2006.

[7] J. R. Galbraith, “Organization Desung,” Addison-Wesley, Reading, 1977.

[8] M. L. Tushman and D. A. Nadler, "Information Processing as an Integrating Concept in Organizational Design," Academy of Management, Vol. 3, No. 3, 1978, pp. 613624. 
[9] K. E. Weick, "The Social Psykology of Organizing," Addison-Welsey, Reading, 1979.

[10] J. R. Galbraith, “Organization Design: An Information Processing View,” Interfaces, Vol. 4 No. 3, 1974, pp. 28-36. http://dx.doi.org/10.1287/inte.4.3.28

[11] R. L. Daft and R. H. Lengel, "Organizational Information Requirements, Media Richness and Structural Design,” Management Science, Vol. 32, No. 5, 1986, pp. 554-571. http://dx.doi.org/10.1287/mnsc.32.5.554

[12] J. I. Martinez and J. C. Jarillo, "The Evolution of Research on Coordination Mechanisms in Multinational Corporations,” Journal of International Business Studies, Vol. 20, No. 3, 1989, pp. 489-514. http://dx.doi.org/10.1057/palgrave.jibs.8490370

[13] H. Sicotte and A. Langley, "Integration Mechanisms and R\&D Project Performance,” Journal of Engineering and Technology Management, Vol. 7, No. 1, 2000, pp. 1-37. http://dx.doi.org/10.1016/S0923-4748(99)00018-1

[14] J. Nihtilä, "R\&D-Production Integration in the Early Phase of New Product Development in Projects,” Journal of Engineering and Technology Management, Vol. 16, No. 1, 1999, pp. 55-81. http://dx.doi.org/10.1016/S0923-4748(98)00028-9

[15] M. Martinsuo and T. Ahola, "Supplier Integration in Complex Delivery Projects; Comparison between Different Buyer-Supplier Relationships,” International Journal of Project Management, Vol. 28, No. 2, 2010, pp. 107116.

[16] J. Kotlarsky, P. Fenema and L. P. Willcocks, "Developing a Knowledge-Based Perspective on Coordination: The Case of Global Software Projects,” Information Management, Vol. 45, No. 2, 2008, pp. 96-108. http://dx.doi.org/10.1016/j.im.2008.01.001

[17] L. J. Daniel and C. R. Davis, "What Makes High-Performance Teams Excel?” Research Technology Management, Vol. 52, No. 4, 2009, pp. 40-45.

[18] A. S. Chang and F. Y. Shen, "Coordination Needs and Supply of Construction Projects," Engineering Management Journal, Vol. 21, No. 4, 2009, pp. 44-57.

[19] M. J. Cooper and C. S. Budd, "Tying the Pieces Together: A Normative Framework for Integrating Sales and Project Operations,” Industrial Marketing Management, Vol. 36 No. 2, 2007, pp. 173-182. http://dx.doi.org/10.1016/j.indmarman.2006.03.005

[20] J. Cornelissen, "Integration in Communication Management; Conceptual Methodological Considerations,” Journal of Marketing Management, Vol. 16, No. 6, 2000, pp. 597-606. http://dx.doi.org/10.1362/026725700785045930

[21] S. W. O’Leary-Kelly and B. E. Flores, “The Integration of Manufacturing and Marketing/Sales Decisions: Impact on Organizational Performance," Journal of Operations Management, Vol. 20, No. 3, 2002, pp. 221-240. http://dx.doi.org/10.1016/S0272-6963(02)00005-0

[22] J. R. Galbraith, "Designing Complex Organizations," Addison-Wesley Longham Publishing Co., Inc., Boston, 1973.

[23] J. R. Galbraith and J. K. Kazanjian, "Strategy Implementation: Structure, Systems and Process," 2nd Edition,
West Publishing Co., St. Paul, 1986.

[24] R. E. Levitt, J. Thomsen, T. R. Christiansen, J. C. Kunz, Y. Jin and C. Nass, "Simulating Projecr Work Processes and Organizations: Towards a Micro-Contingency Theory of Organizational Design,” Management Science, Vol. 45 No. 11, 1999 pp. 1479-1495.

http://dx.doi.org/10.1287/mnsc.45.11.1479

[25] A. Prencipe and F. Tell, "Inter-Project Learning: Processes and Outcomes of Knowledge Codification in Project-Based Firms,” Research Policy, Vol. 30, No. 9, 2001, pp. 1373-1394.

http://dx.doi.org/10.1016/S0048-7333(01)00157-3

[26] M. Hobday, "The Project-Based Organisation: An Ideal Form for Managing Complex Products and Systems?” Research Policy, Vol. 29 No. 7-8, 2000, pp. 871-893. http://dx.doi.org/10.1016/S0048-7333(00)00110-4

[27] R. J. DeFillippi, “Organizational Models for Collaboration in the New Economy," Human Resource Planning, Vol. 25, No. 4, 2002, pp. 7-18.

[28] R. Yin, “Case Study Research,” Sage, Thousand Oaks, 2002.

[29] B. Hellgren and T. Stjernberg, "Design and Implementation in Major Investments-A Project Network Approach,” Scandinavian Journal of Management, Vol. 11 No. 4, 1995, pp. 377-394.

http://dx.doi.org/10.1016/0956-5221(95)00020-V

[30] K. Eloranta, "Supplier Relationship Management in Networked Project Business,” Licentiate’s Thesis, Helsinki University of Technology, Helsinki, 2007.

[31] I. Ruuska, K. Artto, K. Aaltonen and P. Lehtonen, "Dimensions of Distance in a Project Network; Exploring Olkiluoto 3 Nuclear Power Plant Project,” International Journal of Project Management, Vol. 27 No. 2, 2009, pp. 142-153.

http://dx.doi.org/10.1016/j.ijproman.2008.09.003

[32] M. Hoegl and H. G. Gemuenden, “Teamwork Quality and the Success of Innovative Projects: A Theoretical Concept and Empirical Evidence,” Organization Science, Vol. 12, No. 4, 2001, pp. 435-449. http://dx.doi.org/10.1287/orsc.12.4.435.10635

[33] T. Gajendra and G. Brewer, "Collaboration in Public Sector Projects: Unearthing the Contextual Challenges Posed in Project Environments," Engineering Project Organization Journal, Vol. 2 No. 3, 2012, pp. 112-126. http://dx.doi.org/10.1080/21573727.2012.714776

[34] E. Schein, “Organizational Psychology,” 3rd Edition, Prectice-Hall, New Jersey, 1994.

[35] B. Prastad, "What Management Style Is Considered Best for Team-Based Organization and Why?” Journal of ValueBased Management, Vol. 14, No. 1, 2001, pp. 59-77. http://dx.doi.org/10.1023/A:1007836622767

[36] R. Kirhaug, "Conditions for Communication in Risk Exposed Organizations," Journal of General Management, Vol. 36, No. 2, 2010, pp. 22-36.

[37] A. J. Shenhar, "One Size Does Not Fit All Projects: ExPloring Classical Contingency Theory Domains," Management Science, Vol. 47, No. 3, 2001, pp. 394-414. http://dx.doi.org/10.1287/mnsc.47.3.394.9772 
[38] R. Gulati, F. Wohlgezogen and P. Zhelyarkov, "The Two Facets of Collaboration: Cooperation and Coordination in Strategic Alliances," The Academy of Management An- nals, Vol. 6, No. 1, 2012, p 531.

http://dx.doi.org/10.1080/19416520.2012.691646 